\title{
Report of Meloidogyne inornata in common bean in São Paulo State, Brazil
}

\author{
Érika Cristina Souza da Silva Correia ${ }^{1 \mathrm{a}}$, Maria de Fátima Almeida Silva ${ }^{1 \mathrm{a}}$, Bruno Corrêa Aires ${ }^{1 \mathrm{~b}}$, Rogério Peres \\ Soratto $^{1 b}$, Silvia Renata Siciliano Wilcken ${ }^{1 a}$
}

${ }^{1}$ Faculdade de Ciências Agronômicas, UNESP - Universidade Estadual Paulista, ${ }^{a}$ Departamento de Proteção Vegetal, ${ }^{b}$ Departamento de Produção e Melhoramento Vegetal.

Autor para correspondência: Silvia Renata Siciliano Wilcken (srenata@fca.unesp.br)

Data de chegada: 02/06/2016. Aceito para publicação em: 20/06/2016.

$10.1590 / 0100-5405 / 2196$

Meloidogyne inornata Lordello, 1956, was described from specimens of soybeans in São Paulo State, Brazil. For a long time, there have been no reports of this species. In 2008, it was again found in yacon (Polymia sonchifolia), São Paulo State, when the species was revalidated and redescribed. In 2012, it was reported in common bean (Phaseolus vulgaris L.) in Araucária and Santana do Itararé, Paraná State. In December 2013, roots of bean 'BRS Notável' from Lageado Experimental Farm in Botucatu (SP) were received for analysis at the Laboratory of Nematology (FCA/UNESP - Botucatu). They exhibited typical galls but no symptoms in the shoots. The roots were dissected to withdraw the females used in the perineal pattern and esterase isoenzyme phenotype studies. The identification was complemented by analyzes of morphological and morphometric parameters of females, males and second-stage juveniles under an optical microscope. It was identified as Meloidogyne inornata (Figure 1). The perineal patterns of M. inornata females showed a large dorsal arch, composed of smooth to wavy striae, similar to those of $M$. incognita. The excretory pore was located at $46 \mu \mathrm{m}$ from the anterior region, according to the description of M. inornata (25-
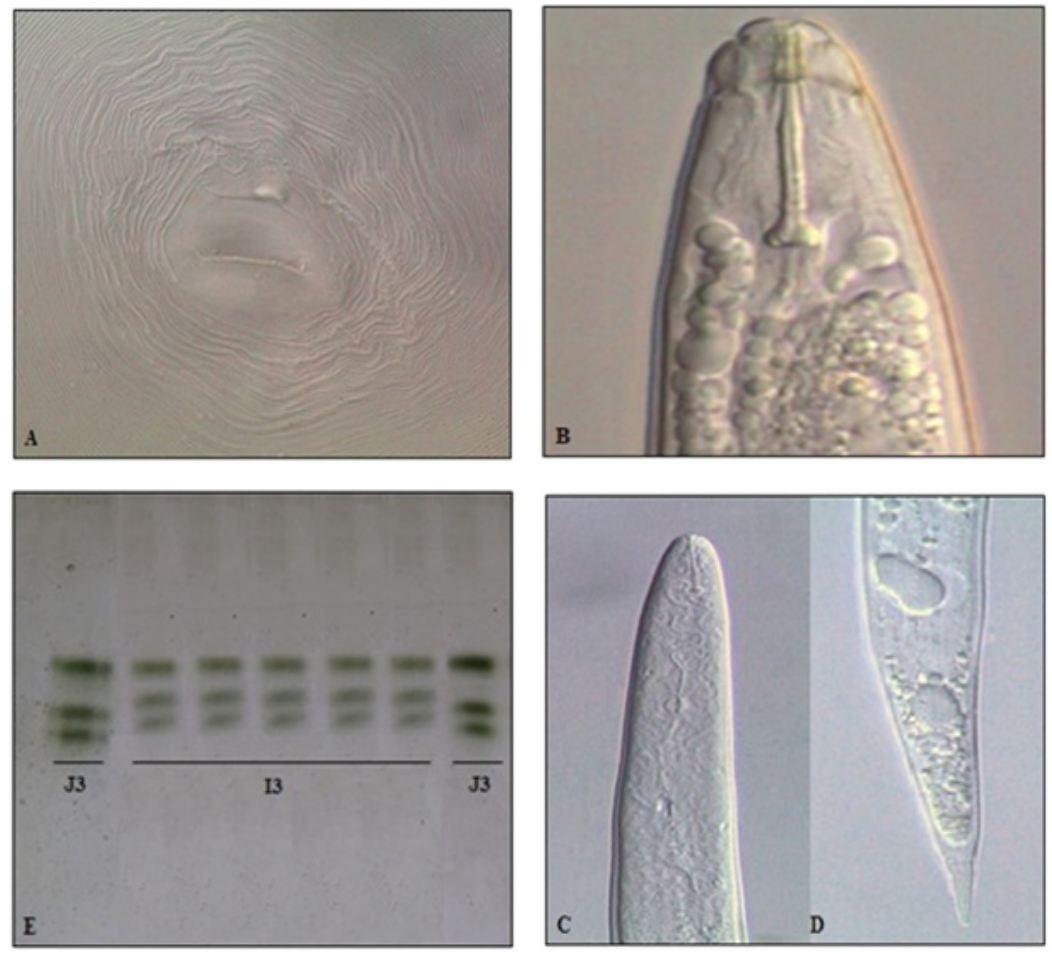

Figure 1. Morphological, morphometric and phenotypic parameters of Meloidogyne inornata. $\mathrm{A}=$ perineal configuration; $\mathrm{B}=$ anterior region of a male; $\mathrm{C}=$ anterior region of a second-stage juvenile $(\mathrm{J} 2) ; \mathrm{D}=$ tail area of a second-stage juvenile $(\mathrm{J} 2)$ and $\mathrm{E}=$ esterase isozyme phenotypes: $\mathrm{I} 3$ of M. inornata and $\mathrm{J} 3$ of $M$. javanica, used as standard). 